\title{
Effects of temperature increase and nutrient enrichment on phytoplankton functional groups in a Brazilian semi-arid reservoir
}

\author{
Efeito do aumento da temperatura e enriquecimento de nutrientes nos grupos \\ funcionais fitoplanctônicos de um reservatório brasileiro do semiárido
}

Maria da Conceição de Souza ${ }^{1}$, Luciane Oliveira Crossetti ${ }^{2}$ and Vanessa Becker ${ }^{1,3 *}$

${ }^{1}$ Programa de Pós-graduação em Ecologia, Universidade Federal do Rio Grande do Norte -UFRN, Av. Senador Salgado Filho, 3000, Campus Universitário, CEP 59078-970, Natal, RN, Brasil

${ }^{2}$ Departamento de Ecologia, Universidade Federal do Rio Grande do Sul - UFRGS, Av. Bento Gonçalves 9500, Campus Universitário, CEP 91501-970, Porto Alegre, RS, Brasil

${ }^{3}$ Departamento de Engenharia Civil, Universidade Federal do Rio Grande do Norte - UFRN, Av. Senador Salgado Filho, 3000, Campus Universitário, CEP 59078-970, Natal, RN, Brasil *e-mail: becker.vs@gmail.com

Cite as: Souza, M.C., Crossetti, L.O. and Becker, V. Effects of temperature increase and nutrient enrichment on phytoplankton functional groups in a Brazilian semi-arid reservoir. Acta Limnologica Brasiliensia, 2018, vol. 30, e215

Abstract: Aim: Our study aimed to evaluate changes in the phytoplankton functional groups brought about by increases in temperature and nutrients predicted by the Intergovernmental Panel on Climate Change (IPCC) scenario for semi-arid regions. Methods: Two experiments were performed, one in the rainy season and another in the dry season. The nutrient enrichment was based on the annual mean values (August 2012-August 2013) of soluble reactive phosphorus and nitrate verified in the reservoir. The microcosms were exposed to two different temperatures, the five-year average of air temperature in the reservoir (control) and $4^{\circ} \mathrm{C}$ above the control temperature (warming). The experiment was conducted over 12 days; every three days water samples of approximately $60 \mathrm{~mL}$ in volume were taken from the reservoir for chemical and phytoplankton analysis. All species were classified by Reynolds Functional Groups (RFG). Results: The functional groups $\mathbf{H}_{1}, \mathbf{X}_{1}, \mathbf{L}_{\mathbf{0}}$ and $\mathbf{S}_{1}$ were the most representative in both seasons (rainy and dry). Our results showed that bloom-forming cyanobacteria, in particular the species of functional groups $\mathbf{H}_{1}$ and $\mathbf{M}$, commonly reported in reservoirs in semi-arid regions of Brazil, were not significantly benefited by the warming and nutrient enrichment. The recruitment of other blue-green species, as well as diatoms and green algae, could be observed. Conclusions: The effects of warming and/or nutritional enrichment can change the structure of the phytoplankton community. However, as not expected as the pessimist scenario, in our study the bloom-forming phytoplankton functional groups did not show changes in relative biomass. Instead, the recruitment of diatoms and green algae currently found in enriched environments was verified, specifically in the rainy period, when nutrient dilution typically occurs.

Keywords: cyanobacteria; experiment; warming; reservoir.

Resumo: Objetivo: Nosso estudo teve como objetivo avaliar, através de escala experimental, mudanças dos grupos funcionais fitoplanctônicos devido ao aumento de temperatura e nutrientes fornecidos pelo cenário do IPCC para a regiấo semiárida. Métodos: Foram realizados dois experimentos, um no período chuvoso e outro no período seco. A água coletada no reservatório foi enriquecida com nutrientes (nitrato e fósforo solúvel reativo) em diferentes concentraçôes. Os microcosmos foram submetidos a duas temperaturas diferentes, média de cinco anos da temperatura do ar no 
reservatório (controle) e $4^{\circ} \mathrm{C}$ acima da temperatura de controle (aquecimento). $\mathrm{O}$ experimento demorou 12 dias e a cada 3 dias cerca de $60 \mathrm{~mL}$ de água eram retiradas para as análises químicas e do fitoplâncton. Todas as espécies foram classificadas pelos grupos funcionais de Reynolds. Resultados: os grupos funcionais $\mathbf{H}_{1}, \mathbf{X}_{1}, \mathbf{L}_{\mathbf{O}}$ e $\mathbf{S}_{\mathbf{1}}$ foram os mais representativos em ambas as estaçóes (chuvosa e seca). Nossos resultados mostraram que as cianobactérias formadoras de floraçóes, especialmente as espécies de grupos funcionais $\mathbf{H}_{1}$ e $\mathbf{M}$, que são comumente relatadas em reservatórios da região semiárida brasileira, não foram significativamente beneficiadas pelo enriquecimento de nutrientes e aquecimento. $\mathrm{O}$ recrutamento de outras espécies de cianobactérias, bem como diatomáceas e algas verdes foram observadas. Conclusóes: Os efeitos do aquecimento e/ou do enriquecimento nutricional podem alterar a estrutura da comunidade fitoplanctônica. Entretanto, como náo esperado no cenário pessimista, em nosso estudo, os grupos funcionais formadores de floração náo mostraram mudanças na sua biomassa relativa. Em vez disso, o recrutamento de diatomáceas e algas verdes, atualmente encontradas em ambientes enriquecidos, foi verificado, especialmente no período chuvoso, quando geralmente há diluição dos nutrientes.

Palavras-chave: cianobactéria; experimento; aquecimento; reservatório.

\section{Introduction}

Global temperatures are rising, causing changes in seasonality and precipitation (IPCC, 2013). Current predictions indicate that temperatures will increase significantly compromising water availability, water quality, agricultural production and economies, and ecosystems. In freshwater bodies, nutrient inputs and increasing temperatures may increase eutrophication and trigger the occurrence of cyanobacteria (Moss et al., 2011). Climate change is therefore a strong catalyst for the expansion of blue-green algae blooms (Paerl \& Huisman, 2009).

Cyanobacteria blooms, in particular potentially toxic blooms, have been reported in many parts of the world (Sukenik et al., 2012). This expansion has been attributed to global temperature increases and the enrichment of nutrients such as phosphorus and nitrogen in bodies of water (Schindler, 1975; Anderson et al., 2002; Paerl \& Huisman, 2008; Moss et al., 2011). In general, cyanobacteria grow quickly in temperatures above $25^{\circ} \mathrm{C}$, being faster than eukaryotic algae (Coles \& Jones, 2000; Butterwick et al., 2005; Reynolds, 2006).

Climate models indicate that arid and semi-arid areas are more susceptible to climate change (IPCC, 2013). Semi-arid watersheds in Brazil tend to be more sensitive to reduced rainfall and water flow compared to humid tropical systems (Roland et al., 2012), which may lead to changes in water levels and hydraulic retention times. These factors may contribute to nutrient concentration and intensified eutrophication (Jeppesen et al., 2015). Some studies performed during drought events in semi-arid regions have shown changes in phytoplankton dynamics, including a predominance of cyanobacteria (Dantas et al., 2011; BittencourtOliveira et al., 2013; Medeiros et al., 2015).
In order to understand the effects of global warming on phytoplankton, many researchers have carried out experiments in which temperature and/or nutrient levels are manipulated. Most experiments that evaluated the response of phytoplankton to increased temperatures were conducted in monocultures using temperatures higher than those predicted by climate models (Coles \& Jones, 2000; Butterwick et al., 2005; Lürling et al., 2013). Few studies have assessed the effects of increased temperature on natural communities (Moss et al., 2003; Lassen et al., 2010). In these communities, it is expected that the warming will influence the composition and abundance of phytoplankton by favoring the tolerant species (Winder \& Sommer, 2012).

The phytoplankton functional groups approach (Reynolds et al., 2002) applied to aquatic systems has provided important information for understanding of the dynamics of species selection. Several studies in phytoplankton ecology have adopted this functional approach in order to understand changes in aquatic ecosystems based on the physiological, morphological, and ecological traits of the species (Becker et al., 2010; Kruk et al., 2017; Santana et al., 2017). This approach (RFG or Reynolds Functional Groups, according to Kruk et al., 2017), is widely used in ecological studies of freshwater phytoplankton and is applicable to different types of environments around the globe. Nowadays the classification includes a total of 40 RFGs (Padisák et al., 2009).

Several studies in semi-arid regions note that drought increases the risk of salinization, thereby aggravating the symptoms of eutrophication and increasing the intensity of cyanobacteria blooms (Costa et al. 2016; Brasil et al., 2016). Then, our study aimed to evaluate the influence of temperature increase and nutrient enrichment on 
phytoplankton functional groups, in a microcosm experiment, of a tropical reservoir located in the Brazilian semi-arid region, based on IPCC (2007) scenarios. In light of the extreme events predicted for semi-arid tropical regions, including severe drought and eutrophication in water bodies, we hypothesized that the experimental warming and/or nutrient enrichment would favor bloom-forming cyanobacteria functional groups.

\section{Material and Methods}

\subsection{Study area}

Subsurface water samples were collected in the rainy (May) and dry (September) seasons of 2013, in the pelagic zone of the Boqueirão de Parelhas

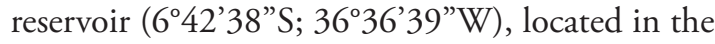
Piranhas-Assú watershed in the semi-arid region of northeastern Brazil. The regional climate is tropical semi-arid (BS'h', Alvares et al., 2013), characterized by irregular rainfall, high evapotranspiration rates, and negative water balance during most of the year. The reservoir has a maximum capacity of $85 \times 10^{6} \mathrm{~m}^{3}$, although its volume does not exceed $10 \times 10^{6} \mathrm{~m}^{3}$ of water and its maximum depth is $13 \mathrm{~m}$. In 2012, the reservoir was considered mesotrophic without thermal or chemical stratification (Galvão et al., 2014). But, due to a prolonged drought, evidenced in 2013, the reservoir changed from mesotrophic to eutrophic state (Gomes, 2016). From 1960 to 2006 , the mean annual precipitation was $726 \mathrm{~mm}$, with a well-defined rainy season between January and July, and an almost complete lack of precipitation (dry season) during the remaining months (Brasil et al., 2016). The reservoir is used for multiple purposes including drinking water, irrigation, recreation, and fishing.

\subsection{Experiment design}

Water samples were collected from the reservoir, transferred to $20 \mathrm{~L}$ bottles, and immediately taken to the laboratory to begin the experiments. The experiments were conducted by using transparent glass $1 \mathrm{~L}$ beckers, which were filled with water from the sample, with four replicates, for temperature manipulation and nutrient addition. Each day the beckers were manually shaken and submitted to a 12:12 hours light/dark photoperiod. The experiment went on for 12 days; every three days, $60 \mathrm{~mL}$ of water was collected from each becker for chemical analysis and phytoplankton quantification.

For the temperature manipulation, the scenario A2 of IPCC (2007) was considered, taking into account an increase of $4{ }^{\circ} \mathrm{C}$. Thus, based on the mean values of five years of temperature recorded for the reservoir region, the control temperature was considered $26^{\circ} \mathrm{C}$ e $27^{\circ} \mathrm{C}$ for dry and rainy season, respectively, and that of the treatment simulating the heating was $30^{\circ} \mathrm{C}$ and $31{ }^{\circ} \mathrm{C}$. For this, two independent incubators were used.

To simulate nutrient loading, solutions of $\mathrm{NaNO}_{3}$ and $\mathrm{KH}_{2} \mathrm{PO}_{4}$ were added to the microcosms on the first day of experiment in an attempt to simulate a punctual release of nutrients. The nutrient enrichment was based on the annual mean values (August 2012 - August 2013) of soluble reactive phosphorus and nitrate verified in the reservoir $\left(4.47 \mu \mathrm{g} \mathrm{L}^{-1}\right.$ and $237.30 \mu \mathrm{g} \mathrm{L}^{-1}$, respectively). The enrichment was performed as follows: (i) treatment C, control treatment, without nutrient enrichment; (ii) treatment P2, enriched with twice the mean concentration of soluble reactive phosphorus; (iii) treatment N2, enriched with twice the mean concentrations of nitrate; (iv) treatment $\mathrm{P} 2+\mathrm{N} 2$, the combination of $\mathrm{P} 2$ and N2; (v) treatment P4, enriched with four times the mean concentration of soluble reactive phosphorus; (vi) treatment N4, enriched with four times the mean concentration of nitrate; and (vii) treatment $\mathrm{P} 4+\mathrm{N} 4$, the combination of $\mathrm{P} 4$ and $\mathrm{N} 4$.

\subsection{Phytoplankton community}

Phytoplanktonic organisms were identified, whenever possible, at the species level. For quantitative analysis, phytoplankton abundance was estimated according to Utermöhl (1958), in inverted microscope, at 400x magnification. Individuals (cells, cenobia, colonies and filaments) were listed in random fields (Uhelinger, 1964). The biovolume $\left(\mathrm{mm}^{3} \mathrm{~L}^{-1}\right)$ was calculated on the basis of approximate geometric models (Hillebrand et al., 1999), assuming the unit of fresh weight expressed in mass $\left(\mathrm{mg} \mathrm{L}^{-1}\right)$. Species richness was estimated by the number of taxa and the diversity index as established by Shannon \& Weaver (1963).

The descriptor species were defined as those that contributed with more than $5 \%$ of the total biomass. All species were classified into functional groups, based on Reynolds et al. (2002) and Padisák et al. (2009).

\subsection{Data analysis}

Box plot analysis was performed to access the biological data variation. Two-way blocking analysis of variance (ANOVA) was performed to evaluate the effect of warming (block) and nutrient enrichment 
on phytoplankton functional groups. The data were transformed $\left(\log _{10}(x+1)\right)$ to meet the assumptions of ANOVA. In all statistically significant situations $(\mathrm{p}<0.05)$ the Tukey Honest Significant Difference (HSD) test was applied. The statistical analyses were performed using STATISTICA ${ }^{\circ}$ software v. 11.

\section{Results}

A total of 28 phytoplankton species of three major taxonomic categories (Cyanobacteria, Chlorophyceae and Bacillariophyceae) were distributed in 12 phytoplankton functional groups (Table 1). The phytoplankton functional groups $H_{1}, X_{1}, L_{0}$ and $S_{1}$ were the most representative in both seasons.

Significant decrease of phytoplankton total biomass $(\mathrm{F}=3.7 ; \mathrm{p}=0.05)$ was verified under the temperature increase in the dry season experiments (Figure 1). Following this same tendency, the warming effect also significantly influenced the biomass increase of Bacillariophyceae in the dry period $(\mathrm{F}=7.7 ; \mathrm{p}=0.007)$ and its decrease in the rainy season $(\mathrm{F}=7.6 ; \mathrm{p}=0.007)$, which was also observed for Chlorophyceae biomass $(F=8.4$; $\mathrm{p}=0.005)$. Species richness increase in the rainy season $(F=4.0 ; \mathrm{p}=0.04)$ and decrease in the diversity values $(\mathrm{F}=9.2 ; \mathrm{p}=0.003)$ in the dry season were also assigned to the isolated effect of temperature rising (Figures 2, 3). Significant influence of nutrient enrichment on the phytoplankton total biomass, major group contribution, species richness or diversity of both rainy and dry periods was not verified.

Biomass of phytoplankton functional groups $\mathbf{B}, \mathbf{S}_{\mathbf{1}}$ and $\mathbf{X}_{1}$ were significantly influenced by the temperature manipulation and nutrient enrichment only during the rainy season experiments (Figure 4). The warming led to the decrease in the biomass of $\mathbf{B}(\mathrm{F}=9.4 ; \mathrm{p}=0.003)$ and $\mathbf{S}_{1}(\mathrm{~F}=6.2 ; \mathrm{p}=0.015)$ and increase of $X_{1}(F=69.5 ; p=0.000)$. The nutrient enrichment, in turn, led to the significant increase of the biomass of the functional group $\mathbf{B}$ in the treatment $\mathrm{P} 4+\mathrm{N} 4(\mathrm{~F}=3.0 ; \mathrm{p}=0.012)$, of $\mathbf{S}_{1}$ biomass in the treatment $\mathrm{P} 2(\mathrm{~F}=4.5 ; \mathrm{p}=0.000)$ and $\mathrm{X}_{1}$ functional group biomass in all the enriched treatments, specially $\mathrm{P} 4+\mathrm{N} 4(\mathrm{~F}=3.6 ; \mathrm{p}=0.003)$.

Regarding the biomass of the functional groups in the dry season experiments, the warming effect

Table 1. Functional groups, descriptor species and corresponding taxonomic groups found during rainy and dry seasons in microcosm experiments.

\begin{tabular}{|c|c|c|}
\hline $\begin{array}{c}\text { Functional } \\
\text { Group }\end{array}$ & Descriptor(s) specie(s) & $\begin{array}{c}\text { Taxonomic } \\
\text { Group }\end{array}$ \\
\hline $\mathrm{H}_{1}$ & $\begin{array}{l}\text { Dolichospermum planctonica (Brunnthaler) Wacklin, L. Hoffmann \& Komárek } 2009 \\
\text { Aphanizomenon gracile Lemmermann }\end{array}$ & Cyanobacteria \\
\hline $\mathbf{K}$ & $\begin{array}{l}\text { Aphanocapsa sp. Nägeli } \\
\text { Aphanothece sp. Nägeli }\end{array}$ & Cyanobacteria \\
\hline $\mathbf{Z}$ & Chroococcus sp. Nägeli & Cyanobacteria \\
\hline $\mathrm{L}_{0}$ & $\begin{array}{l}\text { Coelosphaerium cf. aerugineum Lemmermann } \\
\text { Coelosphaerium sp. Nägeli } \\
\text { Radiocystis sp Skuja } \\
\text { Lemmermanniella sp. Geitler }\end{array}$ & Cyanobacteria \\
\hline & Gloeococystis sp. Nägeli & Chlorophyceae \\
\hline $\mathbf{M}$ & Microcystis aeruginosa (Kützing) Kützing & Cyanobacteria \\
\hline $\mathbf{S}_{1}$ & $\begin{array}{l}\text { Pseudanabaena mucicola (Naumann \& Huber-Pestalozzi) Schwabe } \\
\text { Planktolyngbya limnetica (Lemmermann) Komárková-Legnerová \& Cronberg } \\
\text { Planktothrix isothrix (Skuja) Komárek \& Komárková } \\
\text { Pseudanabaenaceae K.Anagnostidis \& J.Komárek }\end{array}$ & Cyanobacteria \\
\hline B & Cyclotella sp. (Kützing) Brébisson & Bacillariophyceae \\
\hline $\mathbf{D}$ & Nitzschia sp. Hassal & Bacillariophyceae \\
\hline $\mathbf{J}$ & $\begin{array}{l}\text { Crucigenia sp. Morren } \\
\text { Senedesmus sp. Meyen }\end{array}$ & Chlorophyceae \\
\hline$X_{1}$ & $\begin{array}{l}\text { Synechocystis salina Wislouch } \\
\text { Monoraphidium irregulare (G.M.Smith) Komárková-Legnerová }\end{array}$ & $\begin{array}{l}\text { Cyanobacteria } \\
\text { Chlorophyceae }\end{array}$ \\
\hline $\mathbf{F}$ & $\begin{array}{l}\text { Kirchneriella lunaris (Kirchner) Möbius } \\
\text { Kirchneriella obesa (West) West \& G.S.West } \\
\text { Kirchneriella sp. Schmidle } \\
\text { Eutetramorus sp. Walton }\end{array}$ & Chlorophyceae \\
\hline $\mathbf{P}$ & Aulacoseira granulata (Ehrenberg) Simonsen & Bacillariophyceae \\
\hline
\end{tabular}


a.
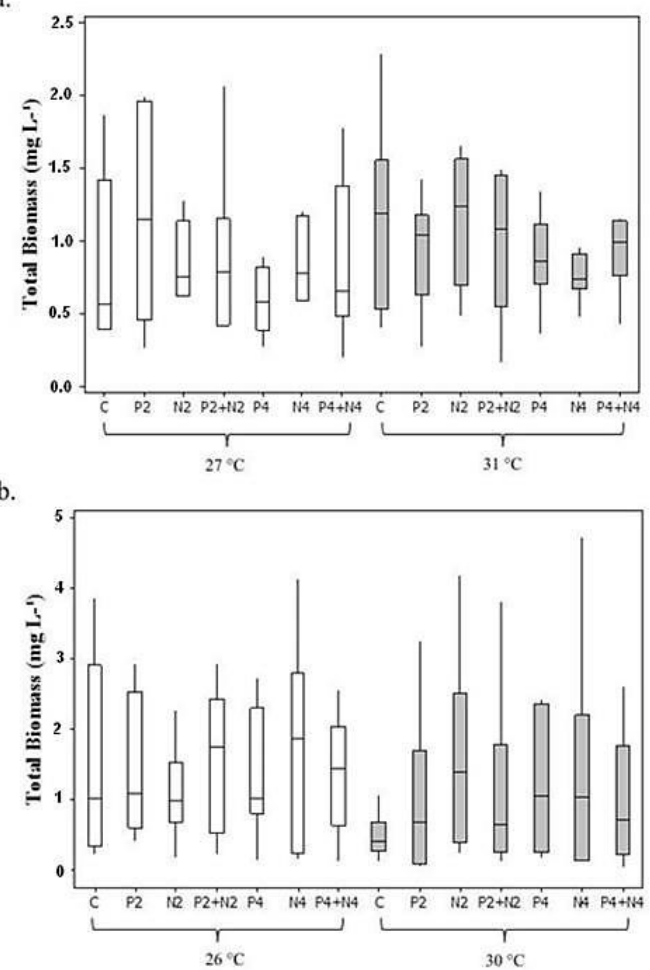

Figure 1. Variation (medians and quartiles, $\mathrm{n}=8$ ) of the total biomass $\left(\mathrm{mg} \mathrm{L}^{-1}\right)$ in different nutritional enrichment and temperature treatments, for the rainy season (a) and dry season (b). White bars represent the temperature control treatments and the ashes the warming temperature treatments.

significantly influenced the decrease of $\mathbf{L}_{\mathbf{O}}(\mathrm{F}=7.1$; $\mathrm{p}=0.009)$. The functional group $\mathbf{F}$ was the only one influenced by the nutritional enrichment in the dry season $(\mathrm{F}=3.5 ; \mathrm{p}=0.003)$, by its biomass increase observed specially in the treatment $\mathrm{P} 4+\mathrm{N} 4$ (Figure 4). Although there was a trend of increasing biomass in the $\mathbf{H}_{1}$ group by the nutritional enrichment in the dry season (Figure 4), it was not considered significant by ANOVA.

\section{Discussion}

Our study evidenced that temperature and/or nutrient manipulation influences the structure and composition of the phytoplankton community in Boqueirão de Parelhas reservoir.

Climate models predict increases in temperature in the coming years, and these changes are associated with nutrient enrichment in water bodies. The effects of nutrient increase include the proliferation of potentially toxic cyanobacteria (Paerl \& Paul, 2012). This proliferation was expected in the present study, however, our results showed a.

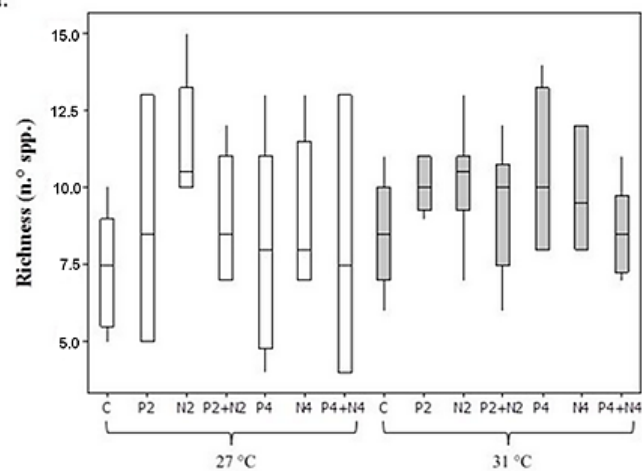

b.

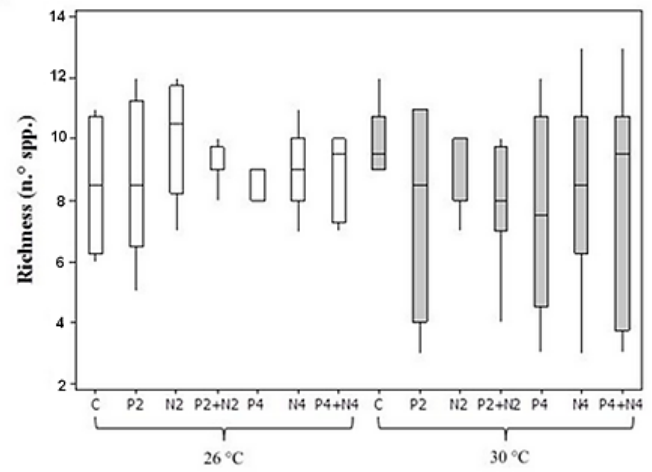

Figure 2. Variation (medians and quartiles, $\mathrm{n}=8$ ) of the species richness ( $n^{\circ}$ spp.) in different nutritional enrichment and temperature treatments, for the rainy season (a) and dry season (b). White bars represent the temperature control treatments and the ashes the warming temperature treatments.

that bloom-forming cyanobacteria, specifically species of functional groups $\mathbf{H}_{1}$ and $\mathbf{M}$ which are commonly reported in reservoirs of the Brazilian semi-arid region (Costa et al., 2009; Dantas et al., 2011; Bittencourt-Oliveira et al., 2013), were not significantly more abundant after exposure to higher temperatures and nutrient enrichment. Instead, the recruitment of other cyanobacteria species as well as diatoms and green algae could be observed.

Although there is clear consensus in the literature that cyanobacteria will proliferate in increasing temperatures and that eukaryotic algae growth rates decline in temperatures that are optimal for blue-green algae (Paerl \& Otten 2013; Kosten et al., 2012; Reynolds, 2006), some studies have shown that higher temperatures do not offer a clear advantage for cyanobacteria over its competitors, even when temperatures are ideal. Studies have also shown that there are no significant differences between the replication rates of Cyanobacteria and Chlorophyceae when subjected to a temperature of $29^{\circ} \mathrm{C}$ (Lurling et al., 2013). Moss et al. (2003) 
a.

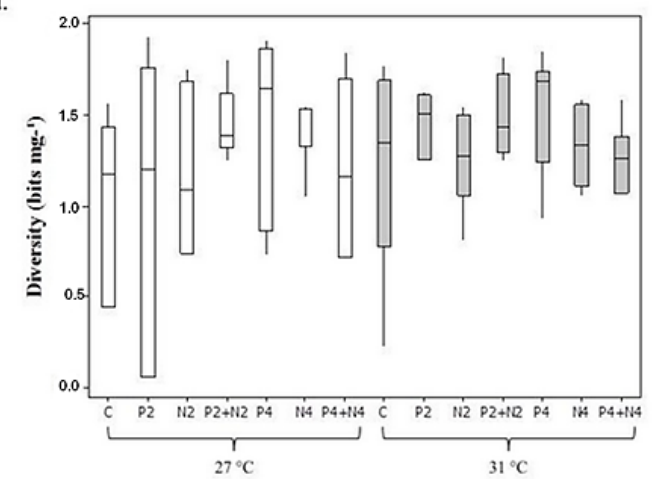

b.

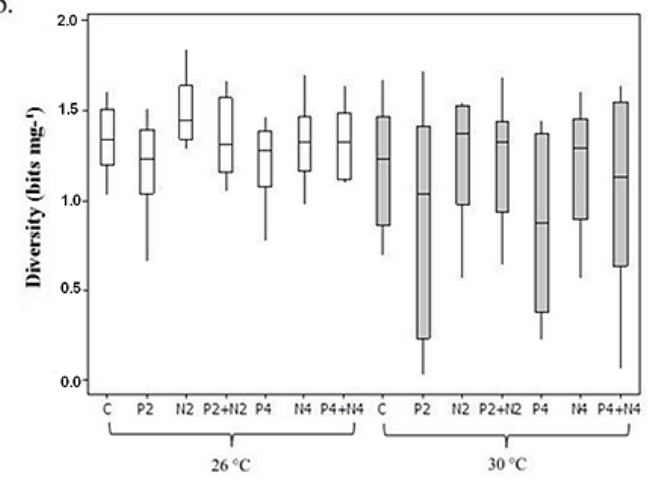

Figure 3. Variation (medians and quartiles, $n=8$ ) of the diversity (bits $\mathrm{mg}^{-1}$ ) of the phytoplankton community in different nutritional enrichment and temperature treatments, for the rainy season (a) and dry season (b). White bars represent the temperature control treatments and the ashes the warming temperature treatments.
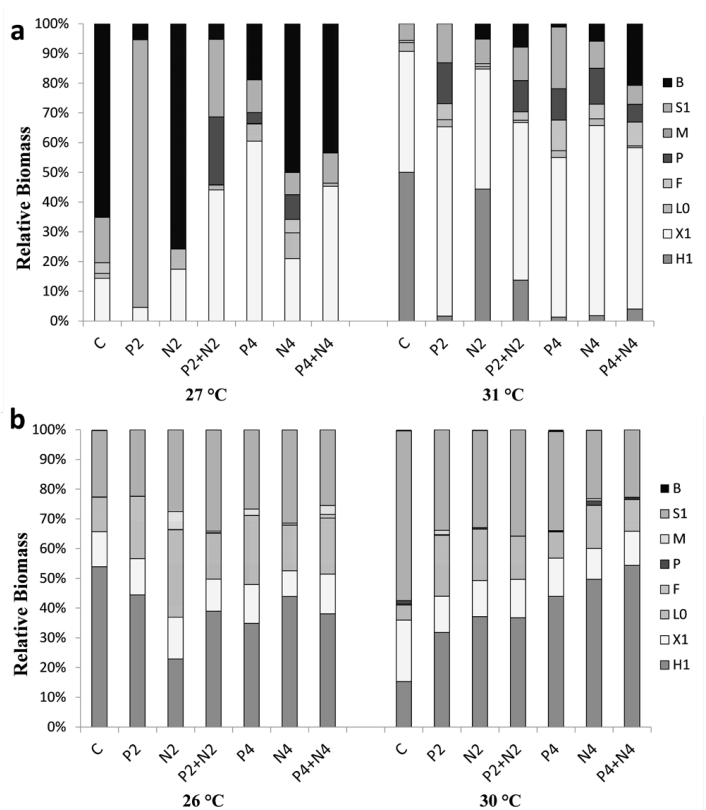

Figure 4. Relative biomass (\%) of the Reynolds Functional Groups (RFG) in different nutritional enrichment and temperature treatments, for the rainy season (a) and dry season (b). demonstrated that two species of green algae (Tetraedron minimum and Micractinium pusillum, which belong to the functional groups $\mathbf{J}$ and $\mathbf{F}$, respectively) proliferated significantly in higher temperatures. Cyanobacteria species were not affected by temperature manipulation. The same results were observed in this study. For example, the functional group $\mathbf{F}$ was the only one recruited in both rainy and dry seasons; it was influenced by temperature increase (rainy and dry seasons) and nutrient enrichment, particularly in treatment $\mathrm{P} 4+\mathrm{N} 4$ (dry season). This codon is usually associated with meso-eutrophic conditions (Padisák et al., 2009).

Phytoplankton studies in the semi-arid region have shown that cyanobacteria are predominant (Bouvy et al., 2000; Costa et al., 2009; Medeiros et al., 2015; Brasil et al., 2016). However, the phytoplanktonic composition has been shifting between colonial and filamentous morphotypes due to different adaptive strategies driven by the hydrological regime (Medeiros et al., 2015). During the rainy season, the inflow from tributaries and overflow reservoir contributed to the lower phytoplankton biomass, and modified the populations of cyanobacteria, favoring the dominance of filamentous species, such as Cylindrospermopsis raciborskii (functional group $\mathbf{S}_{\mathrm{N}}$ ), with these adaptive conditions, turbid, warm and mixed lake (Reynolds et al., 2002). During the dry season, longer periods of water retention favored the growth of colonial cyanobacteria species such as Microcystis panniformis and Sphaerocavum brasiliensis (group $\mathbf{M}$ ), which contributed to higher phytoplankton biomass values (Medeiros et al., 2015). In addition, during severe drought conditions, low water levels can favor adaptive phytoplankton species with requirement for low light by inorganic particles such as diatoms (functional group $\mathbf{P}$ and $\mathbf{B}$ ) and cryptomonads (group Y). This unusual behavior of the phytoplankton community appears to contradict expectations in climatic change scenarios (Medeiros et al., 2015; Costa et al., 2016).

In this study, structural changes in the phytoplankton community were observed in the two seasons. In the dry period, the biomass of Chlorophyceae and Bacillariophyceae, species diversity, and functional group variability were significantly influenced in the higher temperature treatment only. All the functional groups that presented significant variation in the rainy period were closely related to the nutritional enrichment. 
These variations may be explained by the dynamics of the semi-arid reservoirs; during the rainy period these reservoirs have more nutrient dilution due to greater water inflow (Medeiros et al., 2015). This would explain the importance of nutrient enrichment as a critical influence on phytoplankton during the rainy period.

The functional group $\mathbf{S 1}$, represented primarily by Planktolyngbya limnetica, was affected by temperature increase and by nutrient manipulation, particularly in P2. This group, composed of non- $\mathrm{N}$ fixing cyanobacteria, is typical of mixed environments, tolerant of shade, and sensitive to the flow of water (Padisák et al., 2009). Note that shade can occur from the proliferation of algae of the $\mathbf{H}_{1}$ group, forming "scum". This functional group may be predominant in the phytoplankton community in periods with no inflow (Devercelli \& O'Farrell, 2013) in eutrophic lakes, and it may also be found in conditions with limited nutrients (Reynolds, 2006; Dembowska et al., 2015).

Several studies on the effects of climate change on phytoplanktonic communities have noted that increased total biomass is an expected result; this is thought to be due to the increase in blooms of cyanobacteria in water bodies (Paerl \& Huisman, 2008). These blooms lead to a decrease in species richness (Paerl \& Paul, 2012; Kosten et al., 2012; Paerl \& Otten, 2013). In the present study, temperature manipulation alone influenced the increase of species richness in the rainy season, specifically related to the recruitment of species belonging to functional groups $\mathbf{X}_{1}$ and $\mathbf{B}$, which have been associated with mixed conditions (Reynolds et al., 2002; Padisák et al., 2009), common in the rainy period in semi-arid regions due to the water input and turbulence (Medeiros et al., 2015).

Studies have shown that if climate change creates conditions that benefit and influence cyanobacteria growth, then the resilience of ecosystems may lead to the development of algal groups other than blue green algae (e.g. Moss et al., 2013). The microcosm has had a role in exploring the consequences of global issues, such as the effect of climate change on species distribution, population dynamic, trophic structure, biodiversity and the impacts of pollution and fisheries on ecosystems (Benton et al., 2007). In addition, the design of experimental studies cannot capture the complexity of ecosystems. More studies are needed to integrate experimental approaches and field observations in order to better understand the effects that climate change may bring to the dynamics of aquatic ecosystems.

In summary, our study showed that temperature increase and nutritional enrichment influenced the functional structure of the phytoplankton community differently in the rainy and dry seasons of Boqueirão de Parelhas reservoir. Our hypothesis that the experimental warming and/or nutrient enrichment would favor bloom-forming cyanobacterial functional groups was refuted. These functional groups of cyanobacteria did not proliferate as expected. Instead, it was observed the recruitment of diatoms and green algae (typically found in enriched environments), in particular during the rainy period.

\section{Acknowledgements}

We would like to thank FINEP/CNPq for financing the project MEVEMUC (registry $n^{\circ}$ 0108064803), Professor Arthur Mattos for his support, and CAPES for granting master's scholarship. We would also like to thank Instituto Federal do Rio Grande do Norte (IFRN) for laboratory support for the experiment. This work also was supported by the Conselho Nacional de Desenvolvimento Cientifico e Tecnológico (CNPq) Process Number: Universal 407783/2016-4.

\section{References}

ALVARES, C.A., STAPE, J.L., SENTELHAS, P.C., GONÇALVES, J.L.M. and SPAROVEK, G. Köppen's climate classification map for Brazil. Meteorologische Zeitschrift, 2013, 22(6), 711-721. http://dx.doi.org/10.1127/0941-2948/2013/0507.

ANDERSON, D.M., GLIBERT, P.M. and BURKHOLDER, J.M. Harmful algal blooms and eutrophication: nutrient sources, composition, and consequences. Estuaries, 2002, 25(4), 704-726. http://dx.doi.org/10.1007/BF02804901.

BECKER, V., CAPUTO, L., ORDÓÑEZ, J., MARCÉ, R., ARMENGOL, J., CROSSETTI, L.O. and HUSZAR, V.L.M. Driving factors of the phytoplankton functional groups in a deep Mediterranean reservoir. Water Research, 2010, 44(11), 3345-3354. http://dx.doi.org/10.1016/j. watres.2010.03.018. PMid:20398914.

BENTON, T.G., SOLAN, M., TRAVIS, J.M.J. and SAIT, S.M. Microcosm experiments can inform global ecological problems. Trends in Ecology \& Evolution, 2007, 22(10), 516-521. http://dx.doi. org/10.1016/j.tree.2007.08.003. PMid:17822805.

BITTENCOURT-OLIVEIRA, M.C.D., PICCINSANTOS, V., MOURA, N.A., ARAGAOTAVARES, N.K. and CORDEIRO-ARAUJO, M.K. 
Cyanobacteria, microcystins and cylindrospermopsin in public drinking supply reservoirs of Brazil. Anais da Academia Brasileira de Ciências, 2013, 86(1), 297-310. http://dx.doi.org/10.1590/00013765201302512. PMid:24676169.

BOUVY, M., FALCÃO, D., MARINHO, M., PAGANO, M. and MOURA, A. PAGANO. M. and MOURA, A. Occurrence of Cylindrospermopsis (Cyanobacteria) in 39 Brazilian tropical reservoirs during 1998 drought. Aquatic Microbial Ecology, 2000, 23(1), 13-27. http://dx.doi.org/10.3354/ ame 023013 .

BRASIL, J., ATTAYDE, J.L., VASCONCELOS, F.R., DANTAS, D.D.F. and HUSZAR, V.L.M. Droughtinduced water-level reduction favors cyanobacteria blooms in tropical shallow lakes. Hydrobiologia, 2016, 770(1), 145-164. http://dx.doi.org/10.1007/ s10750-015-2578-5.

BUTTERWICK, C., HEANEY, S.I. and TALLING, J.F. Diversity in the influence of temperature on the growth rates of freshwater algae, and its ecological relevance. Freshwater Biology, 2005, 50(2), 291-300. http://dx.doi.org/10.1111/j.13652427.2004.01317.x.

COLES, J.F. and JONES, R.C. Effect of temperature on photosynthesis-light response and growth of four phytoplankton species isolated from a tidal freshwater river. Journal of Phycology, 2000, 36(1), 7-16. http:// dx.doi.org/10.1046/j.1529-8817.2000.98219.x.

COSTA, I.A.S, SOUZA CUNHA, S.R., PANOSSO, R., ARAÚJO, M.F.F., SOUZA MELO, J.L. and ESKINAZI-SANT'ANNA, E.M. Dinâmica de cianobactérias em reservatórios eutróficos do semiárido do Rio Grande do Norte. Oecologia Brasiliensis, 2009, 13(2), 382-401. http://dx.doi.org/10.4257/ oeco.2009.1302.11.

COSTA, M.R.A., ATTAYDE, J.L. and BECKER, V. Effects of water level reduction on the dynamics of phytoplankton functional groups in tropical semiarid shallow lakes. Hydrobiologia, 2016, 778(1), 7589. http://dx.doi.org/10.1007/s10750-015-2593-6.

DANTAS, E.W., MOURA, N.A. and BITTENCOURTOLIVEIRA, M.D.C. Cyanobacterial blooms in stratified and destratified eutrophic reservoirs in semiarid region of Brazil. Anais da Academia Brasileira de Ciências, 2011, 83(4), 1327-1338. http:// dx.doi.org/10.1590/S0001-37652011000400019. PMid:22146960.

DEMBOWSKA, E.A., NAPIÓRKOWSKI, P., MIESZCZANKIN, T. and JÓZEFOWICZ, S. Planktonic indices in the evaluation of the ecological status and the trophic state of the longest lake in Poland. Ecological Indicators, 2015, 56, 15-22. http:// dx.doi.org/10.1016/j.ecolind.2015.03.019.

DEVERCELLI, M. and O'FARRELL, I. Factors affecting the structure and maintenance of phytoplankton functional groups in a nutrient rich lowland river. Limnologica-Ecology and Management of Inland Waters, 2013, 43(2), 67-78. http://dx.doi. org/10.1016/j.limno.2012.05.001.

GALVÃO, A.M.F., ROCHA, O., BECKER, V. and MATTOS, A. Aplicaçấo das curvas ABC para a comunidade zooplanctônica em reservatórios do semiárido tropical. In: A. Mattos and K.M.C. Mattos, eds. Projeto MEVEMUC: monitoramento da evaporação e as mudanças climáticas. João Pessoa: Moura Ramos Editora, 2014, pp. 451-477.

GOMES, S.S. Alteração do estado trófico durante um evento de seca prolongada e seus impactos na biomassa algal de um manancial tropical da região semiárida [Dissertação de Mestrado em Engenharia Sanitária]. Natal: Universidade Federal do Rio Grande do Norte, 2016.

HilleBRAND, H., DÜRSELEN, C.D., KIRSCHTEL, D.B., POLLINGHER, U. and ZOHARY, T. Biovolume calculation for pelagic and benthic microalgae. Journal of Phycology, 1999, 35(2), 403-424. http://dx.doi.org/10.1046/j.15298817.1999.3520403.x.

INTERGOVERNMENTAL PANEL ON CLIMATE CHANGE - IPCC. Climate Change 2007: Impacts, Adaptation and Vulnerability. Contribution of Working Group II to the Fourth Assessment Report of the Intergovernmental Panel on Climate Change. Cambridge: Cambridge University Press, 2007, $976 \mathrm{p}$.

INTERGOVERNMENTAL PANEL ON CLIMATE CHANGE - IPCC. Climate Change 2013: The Physical Science Basis. Contribution of Working Group I to the Fifth Assessment Report of the Intergovernmental Panel on Climate Change Cambridge: Cambridge University Press, 2013, 1535 p.

JEPPESEN, E., BRUCET, S., NASELLI-FLORES, L., PAPASTERGIADOU, E., STEFANIDIS, K., NÓGES, T., NÓGES, P., ATTAYDE, J.L., ZOHARY, T., COPPENS, J., BUCAK, T., MENEZES, R.F., FREITAS, F.R.S., KERNAN, M., SØNDERGAARD, M. and BEKLIOĞLU, M. Ecological impacts of global warming and water abstraction on lakes and reservoirs due to changes in water level and related changes in salinity. Hydrobiologia, 2015, 750(1), 201-227. http://dx.doi. org/10.1007/s10750-014-2169-x.

KOSTEN, S., HUSZAR, V.L.M., BÉCARES, E., COSTA, L.S., DONK, E., HANSSON, L.A., JEPPESEN, E., KRUK, C., LACEROT, G., MAZZEO, N., MEESTER, L., MOSS, B., LÜRliNG, M., NÓGES, T., ROMO, S. and SCHEFFER, M. Warmer climate boosts cyanobacterial dominance in shallow lakes. Global Change Biology, 2012, 18(1), 118-126. http://dx.doi. org/10.1111/j.1365-2486.2011.02488.x. 
KRUK, C., DEVERCELLI, M., HUSZAR, V.L.M., HERNÁNDEZ, E., BEAMUD, G., DIAZ, M., SILVA, L.H.S. and SEGURA, A.M. Classification of Reynolds phytoplankton functional groups using individual traits and machine learning techniques. Freshwater Biology, 2017, 62(10), 1681-1692. http:// dx.doi.org/10.1111/fwb.12968.

LASSEN, M.K., NIELSEN, K.D., RICHARDSON, K., GARDE, K. and SCHLÜTER, L. The effects of temperature increases on a temperate phytoplankton community - A mesocosm climate change scenario. Journal of Experimental Marine Biology and Ecology, 2010, 383(1), 79-88. http://dx.doi.org/10.1016/j. jembe.2009.10.014.

LÜRLING, M., ESHETU, F., FAASSEN, E.J., KOSTEN, S. and HUSZAR, V.L.M. Comparison of cyanobacterial and green algal growth rates at different temperatures. Freshwater Biology, 2013, 58(3), 552-559. http://dx.doi.org/10.1111/j.13652427.2012.02866.x.

MEDEIROS, L.C., MATTOS, A., LURLING, M. and BECKER, $V$. Is the future blue-green or brown? The effects of extreme events on phytoplankton dynamics in a semi-arid man-made lake. Aquatic Ecology, 2015, 49(3), 293-307. http://dx.doi.org/10.1007/s10452015-9524-5.

MOSS, B., JEPPESEN, E., SØNDERGAARD, M., LAURIDSEN, T.L. and LIU, Z. Nitrogen, macrophytes, shallow lakes and nutrient limitation: resolution of a current controversy? Hydrobiologia, 2013, 710(1), 3-21. http://dx.doi.org/10.1007/ s10750-012-1033-0.

MOss, B., KOSTEN, S., MEERhofF, M., BATTARBEE, R.W., JEPPESEN, E., MAZZEO, N., HAVENS, K., LACEROT, G., LIU, Z., MEESTER, L.D.E., PAERL, H. and SCHEFFER, M. Allied attack: climate change and eutrophication. Inland Waters, 2011, 1(2), 101-104. http://dx.doi. org/10.5268/IW-1.2.359.

MOSS, B., MCKEE, D., ATKINSON, D., COLLINGS, S.E., EATON, J.W., GILL, A.B., HARVEY, I., HATTON, K., HEYES, T. and WILSON, D. How important is climate? Effects of warming, nutrient addition and fish on phytoplankton in sallow lake microcosms. Journal of Applied Ecology, 2003, 40(5), 782-792. http://dx.doi.org/10.1046/j.13652664.2003.00839.x.

PADISÁK, J., CROSSETTI, L.O. and NASELLIFLORES, L. Use and misuse in the application of the phytoplankton functional classification: a critical review with updates. Hydrobiologia, 2009, 621(1), 1-19. http://dx.doi.org/10.1007/s10750008-9645-0.
PAERL, H.W. and HUISMAN, J. Climate. Blooms like it hot. Science, 2008, 320(5872), 57-58. http://dx.doi. org/10.1126/science.1155398. PMid:18388279.

PAERL, H.W. and HUISMAN, J. Climate change: a catalyst for global expansion of harmful cyanobacterial blooms. Environmental Microbiology Reports, 2009, 1(1), 27-37. http://dx.doi.org/10.1111/j.17582229.2008.00004.x. PMid:23765717.

PAERL, H.W. and OTTEN, T.G. Harmful cyanobacterial blooms: causes, consequences, and controls. Microbial Ecology, 2013, 65(4), 995-1010. http://dx.doi.org/10.1007/s00248-012-0159-y. PMid:23314096.

PAERL, H.W. and PAUL, V. J. Climate change: Links to global expansion of harmful cyanobacteria. Water Research, 2012, 46(5), 1349-1363. http://dx.doi. org/10.1016/j.watres.2011.08.002. PMid:21893330.

REYNOLDS, C., HUSZAR, V., KRUK, C., NASELLIFLORES, L. and MELO, S. Towards a functional classification of the freshwater phytoplankton. Journal of Plankton Research, 2002, 24(5), 417-428. http://dx.doi.org/10.1093/plankt/24.5.417.

REYNOLDS, C.S. Ecology of phytoplankton (ecology, biodiversity and conservation). Cambridge: Cambridge University Press, 2006. http://dx.doi.org/10.1017/ CBO9780511542145.

ROLAND, F., HUSZAR, V.L.M., FARJALLA, V.F., ENRICH-PRAST, A., AMADO, A.M. and OMETTO, J.P.H.B. Climate change in Brazil: perspective on the biogeochemistry of inland waters. Brazilian Journal of Biology $=$ Revista Brasileira de Biologia, 2012, 72(3, Suppl), 709-722. http:// dx.doi.org/10.1590/S1519-69842012000400009. PMid:23011300.

SANTANA, L.M., CROSSETTI, L.O. and FERRAGUT, C. Ecological status assessment of tropical reservoirs through the assemblage index of phytoplankton functional groups. Brazilian Journal of Botany, 2017, 40(3), 695-704. http://dx.doi. org/10.1007/s40415-017-0373-4.

SCHINDLER, D.W. Whole-lake eutrophication experiments with phosphorus, nitrogen and carbon. Verhandlungen der Internationalen Vereininging für Theoretische und Angewandte Limnologie, 1975, 19(4), 3221-3231. http://dx.doi.org/10.1080/03680770.1 974.11896436.

SHANNON, C.E. and WEAVER, W. The mathematical theory of communication. Urbana: University of Illinois Press, 1963.

SUKENIK, A., HADAS, O., KAPLAN, A. and QUESADA, A. Invasion of Nostocales (cyanobacteria) to subtropical and temperate freshwater lakesphysiological, regional, and global driving forces. Frontiers in Microbiology, 2012, 3, 86. http://dx.doi. org/10.3389/fmicb.2012.00086. PMid:22408640. 
UHELINGER, V. Étude statistique des méthodes de dénombrement planctonique. Archives des Sciences, 1964, 17(2), 121-223. http://dx.doi.org/10.1002/ iroh. 19650500319.

UTERMÖHL, H. Zur Vervollkommung der quantitativen phytoplankton - Methodik. Mitteilungen der Internationale Vereinigung für Theoretische und Angewandte Limnologie. Schweizerbart, 1958, 9, 1-38.
WINDER, M. and SOMMER, U. Phytoplankton response to a changing climate. Hydrobiologia, 2012, 698(1), 5-16. http://dx.doi.org/10.1007/s10750012-1149-2.

Received: 15 June 2017 Accepted: 31 August 2018 